\title{
COPING STRATEGIES OF FARMERS REGARDING THE IMPACT OF CLIMATE CHANGE IN RICE-WHEAT ZONE OF THE PUNJAB, PAKISTAN
}

\author{
Sohail Akhtar*, Ashfaq Ahmad Maann, Kanwal Asghar Awan and Babar Shahbaz \\ ${ }^{1}$ Department of Rural Sociology, University of Agriculture, Faisalabad, Pakistan; ${ }^{2}$ Institute of Agri. Extension \& \\ Rural Development, Faculty of Social Sciences, University of Agriculture, Faisalabad, Pakistan \\ "Corresponding author's email: msohailuaf92@gmail.com
}

\begin{abstract}
Pakistan is one of those countries which are victim of climate change and is already facing many problems like poverty and food insecurity leading to threats to agriculture expansion. Climate change is ahead of all these due to decreasing agriculture production prolonged water scarcity and declined income growth. Agriculture plays a big role in economy of Pakistan and climate change is matter of serious concern. The main objective of the present study was to find out the factors affecting the strategies of farmers regarding the impact of climate change in Punjab, Pakistan. Three districts from rice-wheat cropping zone (Narowal, Sialkot and Gujranwala) were selected randomly. A total sample of four hundred eight respondents was selected by systematic random sample technique. A well-structured interview schedule was used as research instrument for data collection. Collected data were analyzed statistically. In addition, descriptive and inferential statistics were applied for the data analysis. It was found that education level of the farmers was low in the study area. Most farmers had small land holdings and were used to self-cultivation. Mean area of wheat and rice was 7.31 \pm 6.06 and $6.25 \pm 5.60$ acres, respectively. It was observed that long summer and short winter season and high temperature were the main perceptions of climate change in the study area. Industrial smoke, excessive felling of forests and human activities were also perceived as the factors leading to change in environment. A vast majority of the farmers observed that climate change had negative impact on crop production and annual income. It was also found that recommended varieties $(2.58 \pm 0.72)$, applying more industrial pesticides $(2.50 \pm 0.76)$ and practicing crop diversification (2.36 \pm 0.81$)$, increased use of irrigation (2.19 \pm 0.89$)$ and integrated farming system $(02.15 \pm 0.91)$ were the major coping strategies for minimizing the effect of climate changes and these strategies had positive impact on crop productivity. Binary Logistic Model showed that increase in education, income, agricultural experience, contributes in to adoption of strategies to cope climate changes of farmers. It is recommended that farmers should use approved varieties, fertilizers and practice crop diversification. Investment on improved agricultural technology by government and other stakeholders are very necessary for agriculture to be able to cope with climate change.
\end{abstract}

Keywords: Agriculture, climate change, atmospheric heat, greenhouse gases, crop production.

\section{INTRODUCTION}

Climate variation means a change in weather within a specific period of time due to change in natural condition or human activities (Anon, 2007). It also means a change in climate lasting for decades or longer as an outcome of human activity that changes atmosphere, greenhouse gases emission (Oxfam International, 2009; IPCC, 2007a). Present atmospheric heat is due to human activity which leads to increase many gasses in the atmosphere. Half of the gasses (e.g. $\mathrm{CO}_{2}$ ) are absorbed by sea and tree and rest are mounted up in atmosphere (Afzal and Akhtar, 2013).

Climate change is one of the biggest challenges in all over the world. The average annual temperature of earth has risen $0.82^{\circ} \mathrm{C}$ from 1880 to 2012 (Hartmann et al., 2013). Temperature of earth had been warmed on an average by about warmest from 1990 to 2000s (Waston, 2010). The heat of world seas has increased and global mean sea level has gone up by $225 \mathrm{~mm}$ from 1880 to 2012 (Church et al., 2013).
Most of the nations are suffering from rising temperature, melting of glaciers, rising of sea level causing floods leading to increased risk of drought or dangerous floods and these have badly affected the economic sector of many countries of the world. The weather change of South Asia has led to change in water resources, food health, biodiversity, forestry and socio-economic sectors (Field, 2014).

Overall decline in production is supposed between 3 to $16 \%$ but developing countries may face $25 \%$ decrease in product by 2080 . European countries have lower temperature which will show milder or even positive effect on product increase 8 to $6 \%$ decrease by 2080 . South Asian developing countries like India may face decrease of product by 3 to $40 \%$ during the same period (Mahato, 2014). Current variations in climate have affected the people of world as it is matter of change in climate and for other a matter of life and death. It is a reality that developing countries have not increased annual carbon dioxide emission but they are suffering more from its effect (Daze, 2011; Van Aals, 2006). 
Agriculture sector is important which provides raw materials to industry and contributes $19.8 \%$ in GDP and it also absorbs $42.3 \%$ of country's total labour force. Agriculture growth depends on climate temperature but precipitation may affect agricultural product commodity price and economic growth. The policy makers have shifted to develop projects of agriculture during past years as it will increase the foreign exchange reserve. The small farmers are facing problems and they have been figured in lower to middle range of economy trying to provide the food requirement with current rate of development imagine to slip to the lower ranged economy having ability to provide the food needs of population 2030 (GOP, 2017).

In Pakistan two cropping seasons namely Rabi and Kharif are famous. Rabi crops are grown from November to April and Kharif crops are grown from May to October and these two seasons shape the agriculture economy of Pakistan. Wheat which is Rabi crop, was cultivated on 9.05 million hectare in 2016-17 with total yield of 25.750 million tones. During Kharif season rice was cultivated on 2.72 million hectares in 2016-17 with yield of 6.849 million tones. Wheat and rice yield is important for food security and wheat accounts for $9.6 \%$ of total value added in agriculture. The land under production of rice and wheat is mainly unfavorable and this un-favorability is due to water supply, variation in monsoon demonstration and government plan for subscribed prices of crops and support price for raw material (GOP, 2017).

Rice wheat system is one of the main cropping systems of Punjab Pakistan. The rice crop is grown well on puddle part of land, whereas, wheat is grown well on drained land. The well-developed puddling operations supports water retention and weed control. The compacted soil leads to water logging for wheat moreover the traditional land preparation after rice harvesting results late wheat sowing. May and June are important for rice transplanting and October-November have significance for rice harvesting. The rice transplantation and harvesting is fluctuated by monsoon season. The wheat of irrigated regions is affected from temperature fluctuation such as sudden rise in day temperature in February-March (Milky stage) after a long cold and wet spell cause shrinking of grains. This biological cycle affect the grain size, weight and starch contents leading to decrease in grain yield. However, crop production is not affected due to precipitation as water supply is sustainable because of canal irrigation until prolong drought grips. Wheat and rice of the main crops largely being consumed as staple food and food security mainly revolve around both the crops (GOP, 2013).

Agriculture sector is guaranteeing food security and alleviating poverty. Atmospheric heat increases in evapotranspiration causing increase in irrigation need and increasing warming pressure on crop. The introduction of short period crop cultivars and arrangement in sowing time may reduce the negative effect of predicted weather risk. The low land fertility of semi-arid and dry land of Pakistan particularly Sindh and Balochistan is victim of climate change as low rain fall increases evapotranspiration resulting drought. Increase in $1{ }^{\circ} \mathrm{C}$ in heat may decrease $5-7 \%$ wheat production (Aggarwal and Sivakumar, 2011). Another report indicates that wheat production is decreased up to 6-9\% in semi-arid and sub humid zone of Pakistan but its production increased in humid region (Sultana and Ali, 2006). An increase in heat by $1.5-3.0^{\circ} \mathrm{C}$ may reduce wheat production by $7-21 \%$ in Swat district, KPK, Pakistan whereas wheat production may increase by $14-23 \%$ in Chitral, Pakistan (Husnain and Mudassar, 2007).

In addition to increase in temperature, low rainfall may affect crop yield adversely. Low rainfall results in low production in cereals, fruits and vegetable. The agricultural and livestock farmers use different strategies to overcome the climate change risk. These adoption measures are taken for adjustment in sowing time of different crops to avoid weather change risk. They are also making efforts to use stresstolerant crop varieties to cover the climate change risk (Smit and Skinner, 2002). Adoption measures e.g., sowing dates, fertilizer use efficiency, irrigation system, crop varieties, irrigation numbers and cultivation methods significantly affect the crop productivity (Challinor et al., 2014). However, farmers are facing difficulties in using these adaptation practices (Porter et al., 2014). These adoptive measures may reduce the influence of climate variation.

The climate change impact on natural and socio-economic segment is important to study which would help to understand and identify the intensity and impact on global climate change. Studies on perceived local knowledge and adoptive strategies at household and community level would provide the basis to understand the concepts and methods to assess the impact of climate change. Therefore, the main objective of the present study was to find out the factors affecting the coping strategies of farmers regarding the impact of climate change in rice-wheat zone of the Punjab, Pakistan.

\section{MATERIALS AND METHODS}

Multi-stage sampling technique was applied for data collection. At the first stage three districts (Narowal, Gujranwala and Sialkot) were selected randomly from ricewheat crop zone of Punjab, at the second stage three tehsils (one tehsil from each district) such as Shakargarh (Narowal district), Noshara Virka (Gujranwala district) and Pasroor (Sialkot district) were selected randomly, at the $3^{\text {rd }}$ stage six Union Councils, 2 from each selected tehsil (UC-90 \& UC-91 from Tehsil Sakargarh, UC-78 \& UC-81 from Tehsil Noshara Virkan and UC-19 \& UC-21 from Tehsil Pasroor) were selected randomly, at the $4^{\text {th }}$ stage 24 villages (four from each UC) were selected randomly and at the last stage a sample size of 408 farmers (17 farmers from each village) were selected by using systematic random sampling technique. 
Data were collected with the help of a comprehensive interview schedule and analyzed by using SPSS-22 software. Descriptive analysis (frequency, percentage, mean, standard deviation) and linear regression model were used for data analysis. In the present study, a binary logistic model was applied to observe the factors influencing the adoption of coping strategies applied by the farmers in the study area. Similar method was applied by Huong et al. (2017) to explore the farmers' awareness and adaptive response about climate change.

\section{RESULTS AND DISCUSSION}

Age: According to age, the respondents were assembled into three classes: (I) $1^{\text {st }}$ category belonged to young farmers (Up to 40 ), (ii) $2^{\text {nd }}$ category belonged to middle-aged (>40-50), and (iii) $3^{\text {rd }}$ belonged to old (>50). The information (data) in this regard are displayed in Table 1, which shows that $29.4 \%$ of the chosen agriculturists (farmers) were of age group (up to 40 ), while $34.6 \%$ and $36.0 \%$ of the chosen ranchers (farmers) belonged to middle age group (41-50), and old (over 50) group, respectively.

It can be inferred from the obtained results that the majority of the chosen growers were of middle and old age groups, while about one-third of them were of young age. This alludes that the farmers in the research area were more experienced. Due to this experience in the field, they were better able to adapt themselves according to the changing circumstances. They were familiar with the changing trends of climate change due to the global warming. The results of the present investigation are as per those of Fawole (2006) and Ofuoku et al. (2008) who found that the greater part of the selected farmers belonged to middle and old age groups respectively.

Education: Around $33 \%$ of the chosen agriculturists were uneducated, while a noteworthy extent (43.9\%) of the selected farmers had the primary-middle level, though just $13.2 \%$ of the respondents were with matriculation (Table 1), and $10 \%$ of them had above matric level education. The discoveries of the information demonstrated that the education level of the agriculturists was low. The above outcomes are comprehensively upheld by Akhtar (2011). Whereas, the conclusions are opposing to those of Arshad (2009) who concluded that a large majority of farmers were illiterate.

Income: The Table 1 uncovers that $33.3 \%$ of the selected farmers had up to Rs. 30,000 monthly income from all sources, while $39.2 \%$ of the chosen peasants had Rs. 30,00140,000 monthly income and $27.5 \%$ of them had above Rs. 40,000 monthly income. The outcome of the present research are contradictory to those of Mehmood (2011) who told that around $32 \%$ farmers had annual income less than Rs. 200,000 per annum from all sources. While around 23, 31 and $14.1 \%$ sampled farmers were having annual income of Rs. 200001 to
300000, 300001-400000 and more than Rs. 400000 , respectively.

Family type: It has been observed that around $40 \%$ of the selected farmers were living in nuclear family system, while less than a half $(48.3 \%)$ of the selected farmers were living in joint and extended (12.3\%) family system (Table 1). According to Mansoor (2008), mostly Pakistani population was living in joint family system.

Family size: It is assumption that large family size is normally associated with a higher labour endowment, which would enable a household to accomplish various agricultural tasks. It was observed regarding family size that $40.4 \%$ of the selected farmers had up to five family members, while $37 \%$ of the respondents had 6-10 family members, and $22.5 \%$ of the respondents had above 10 family members (Table 1).

Table 1. Socio-economic characteristics of the selected farmers $(n=408)$.

\begin{tabular}{lcc}
\hline Socio-economic characteristics & Frequency & Percentage \\
\hline Age (years) & 120 & \\
Up to 40 & 141 & 39.4 \\
$41-50$ & 147 & 36.0 \\
Above 50 & & \\
Education & 134 & 32.8 \\
Illiterate & 179 & 43.9 \\
Primary-Middle & 54 & 13.2 \\
Matric & 41 & 10.0 \\
Above Matric & & \\
Monthly income (Rs.) & 136 & 33.3 \\
Up to 30000 & 160 & 39.2 \\
30001-40000 & 112 & 27.5 \\
Above 40000 & & \\
Family type & 161 & 39.5 \\
Nuclear & 197 & 48.3 \\
Joint & 50 & 12.3 \\
Extended & & \\
Family size (Nos.) & 165 & 40.4 \\
Up to 5 & 151 & 37.0 \\
6-10 & 92 & 22.5 \\
Above 10 & & \\
\hline
\end{tabular}

The number of years completed by a farmer working on the farm and cultivating, harvesting, and irrigating a number of crops is called his farm experience. Longer cultivating background suggests aggregated cultivating learning and expertise, which adds to use of agrarian technologies (Tadesse, 2008). The respondents were divided into three groups based on their farm experience: (i) up to 20 years, (ii) 21-30 years, and (iii) >30 years. Data presented in Table 2 depicts that $32.4 \%$ of the respondents had up to 20 years of farming experience, while $35.5 \%$ of the selected farmers had 21-30 years of farming experience, and $32.1 \%$ of them had above 30 years of working experience. Lewis (1997) was of the view that longer duration of experience on the part of the 
farmer implies that he is exposed to the latest and modern means of cultivation. He can handle the climate changes more effectively as compared to other farmers. Edeoghon et al. (2008) also reported that $32.20 \%$ of the respondents had farming experience of about 20 years which is very much similar to the findings of our research.

Table 2. Farming experience $(n=408)$.

\begin{tabular}{lcc}
\hline $\begin{array}{l}\text { Farming experience } \\
\text { (No. of years) }\end{array}$ & Frequency & Percentage \\
\hline Up to 20 & 132 & 32.4 \\
$21-30$ & 145 & 35.5 \\
Above 30 & 131 & 32.1 \\
Total & 408 & 100.0 \\
\hline
\end{tabular}

Size of land holding implies the measure of farm ran by single agriculturist and his family for crops and animals' production. There is more tendency to adopt larger farm while effectively utilizing the innovative technology (USDA, 2007). There were three categorizes of the farmers who were concerning about land holding size: (i) up to 5 acres of land, (ii) $>5-10$ acres of land, and (iii) $>10$ acres of land. Around 34 of the chosen agriculturists had up to five acres of land, while $45.3 \%$ of the chosen agriculturists had between 5 to 10 acres of land (excluding end points), and $20.8 \%$ of them had over ten acres of land (Table 3). Mean size of land holding was 8.79 acres of land with standard deviation of 7.09 acres of land. So, mostly farmers had >5-10 years acres of land. Comparable discoveries were accounted for by Akhtar (2011).

Table 3. Classification of sampled farmers concerning to land holding size.

\begin{tabular}{lcc}
\hline Size of land holdings (acres) & Frequency & Percentage \\
\hline Up to 5 & 138 & 33.8 \\
$>5-10$ & 185 & 45.3 \\
Above 10 & 85 & 20.8 \\
Total & 408 & 100.0 \\
\hline
\end{tabular}

Mean $=8.79 \quad$ S.D. $=7.09$

In the study area, wheat and rice were the major crops. Among the Rabi season crops wheat is predominant, which was sown on 9.05 million ha in 2016-17 with a yield of 25.750 million tons. Among the Kharif season crops rice is a vital crop, which yielded 6.849 million tones out of 2.72 million ha in 2016- 2017 (Govt. of Pakistan, 2017).

Table 4 reveals that $38.7 \%$ of the selected farmers had up to 4 acres reserved for wheat cultivation, while $38.7 \%$ of the selected farmers had >4-8 acres reserved for wheat cultivation, and $22.5 \%$ of the selected farmers had above 8 acres reserved for wheat cultivation. So, a considerable proportion of the sampled farmers had up to eight acres for wheat cultivation.

About $44.4 \%$ of the selected farmers had up to 4 acres reserved for rice cultivation, while $36.5 \%$ of the selected farmers had $>4-8$ acres reserved for rice cultivation and $19.1 \%$ of the selected farmers had above 8 acres reserved for rice cultivation. It is clear from the above mentioned findings that mostly selected population reserved up to four acres land for rice crop. Mean area of wheat $(7.31 \pm 6.06)$ was high as compared to rice $(6.26 \pm 5.60)$ in the study area.

Table 4. Classification of the selected farmers concerning to area under wheat and rice crops during the previous one year.

\begin{tabular}{lcccc}
\hline \multirow{2}{*}{$\begin{array}{l}\text { Area } \\
\text { (acres) }\end{array}$} & \multicolumn{2}{c}{ Wheat } & \multicolumn{2}{c}{ Rice } \\
\cline { 2 - 5 } Up to 4 & 158 & 38.7 & $\boldsymbol{f}$ & $\mathbf{\%}$ \\
$>4-8$ & 158 & 38.7 & 149 & 44.4 \\
$>8$ & 92 & 22.5 & 78 & 36.5 \\
Total & 408 & 100.0 & 408 & 19.1 \\
\hline \multicolumn{3}{c}{ Mean area $=7.31, \mathrm{SD}=6.06$} & Mean area $=6.25, \mathrm{SD}=5.60$ \\
\hline
\end{tabular}

Table 5 represents the rank order of farmers' perception about causes of climate change. Table showed that the industrial smoke was the cause of climate change $(2.64 \pm 0.69)$ and it was ranked $1^{\text {st }}$ on the basis of farmers' perception about the causes of climate change, while the excessive felling of forests, leads to change in environment $(2.57 \pm 0.68)$ and human activities were causing changes on the earth's climate $(2.51 \pm 0.72)$ were ranked $2^{\text {nd }}$ and $3^{\text {rd }}$, respectively. Whereas, the burning of waste material was the cause of climate change $(2.46 \pm 0.79)$. The excessive use of coal, fuel, oil, and gas on domestic and commercial basis also leads to change in climate $(2.44 \pm 0.79)$ and the excessive use of sub-soil water in agriculture causes the climate to change $(2.37 \pm 0.87)$ were ranked $4^{\text {th }}$ to $6^{\text {th }}$, respectively on the basis of farmers' perception about the particular causes of climate change. Huertas (2015) demonstrated the similar results. According to his research findings, cutting of forests, industrial smoke, and human efforts are the real cause of climate change.

Table 5. Means, standard deviation and rank order of farmers' perception about causes of climate change.

\begin{tabular}{lcccc}
\hline Causes of climate changes & $\begin{array}{c}\text { Weighted } \\
\text { score }\end{array}$ & Mean & S.D & Rank \\
\hline $\begin{array}{l}\text { The industrial smoke is the } \\
\text { cause of climate change }\end{array}$ & 1077 & 2.64 & 0.69 & 1 \\
$\begin{array}{l}\text { The excessive cutting of forest, } \\
\text { leads to change in environment }\end{array}$ & 1047 & 2.57 & 0.68 & 2 \\
$\begin{array}{l}\text { Human activities are causing } \\
\text { changes in the earth's climate }\end{array}$ & 1026 & 2.51 & 0.72 & 3 \\
$\begin{array}{l}\text { The burning of waste material is } \\
\text { the cause of climate change }\end{array}$ & 1002 & 2.46 & 0.79 & 4 \\
$\begin{array}{l}\text { The excessive use of coal fuel, } \\
\text { oil and gas on domestic \& } \\
\text { commercial basis also leads to } \\
\text { change in climate }\end{array}$ & 997 & 2.44 & 0.79 & 5 \\
\hline
\end{tabular}




$\begin{aligned} & \text { The excessive use of sub soil } \\ & \text { water in agri. causes which leads }\end{aligned}$
to change in climate

Scale: $1=$ Disagree, $2=$ Neutral, $3=$ Agree

Table 6 represents the farmers' perception about the consequences of climate change. It was observed that majority of the respondents $(87.5 \%)$ reported that elevated temperature, more rainfall (58.6\%), more humidity (72.3\%), more fog during winter $(83.8 \%)$, more wind storms during summer $(74.0 \%), \operatorname{smog}(87.0 \%)$, shorter winter season $(93.9 \%)$, and longer summer season $(94.6 \%)$ were the major consequences of the climate change. The results presented are very much in line with the findings of (Watson, 2010), high temperature (Farooq et al., 2004), decline in rainfall (Osada et al., 1973) and humidity (Lyngdoh and Baishya, 2010).

Table 6. Farmers' perception about consequences of climate change $(n=408)$.

\begin{tabular}{lccrc}
\hline Consequences of climate change & \multicolumn{3}{c}{ Yes } & \multicolumn{2}{c}{ No } \\
\cline { 2 - 5 } & \multicolumn{1}{c}{$\boldsymbol{f}$} & $\boldsymbol{\%}$ & \multicolumn{1}{c}{$\boldsymbol{f}$} & \multicolumn{1}{c}{$\boldsymbol{\%}$} \\
\hline High temperature & 357 & 87.5 & 51 & 12.5 \\
More rainfall & 239 & 58.6 & 169 & 41.4 \\
More humidity & 295 & 72.3 & 113 & 27.7 \\
More fog during winter & 342 & 83.8 & 66 & 16.2 \\
More wind storms during summer & 302 & 74.0 & 106 & 26.0 \\
Smog & 355 & 87.0 & 53 & 13.0 \\
Shorter winter season & 383 & 93.9 & 25 & 6.1 \\
Longer summer season & 386 & 94.6 & 22 & 5.4 \\
\hline
\end{tabular}

It is obvious from the findings that rise in temperature will reduce the productivity of the crops. Exposure to high temperature will reduce the growing period, crop will mature earlier and resultantly there will be the low production. The regions where temperature is already high, the further increase in temperature will have devastating effect on the crop yield (IPCC, 2007b). The results in regard to agriculturists' assessment about the effect of environmental change on edit efficiency are given in Table 7, which shows that crop production in general is not enough to meet the needs of the people $(2.72 \pm 0.62)$ was ranked $1^{\text {st }}$ on the basis of farmers' opinion about the impact of climate change on the crop productivity, while the statement 'If our agriculture products remain decreasing, we shall have to face food shortage in the future' $(2.72 \pm 0.53)$ and Increased ratio of salt in fertile land leads to low crop production (mean $=2.68 \pm$ $.58)$ were ranked $2^{\text {nd }}$ and $3^{\text {rd }}$, respectively. Whereas, the irregular seasons have badly affected the crop productivity $(2.65 \pm 0.64)$, and $(2.56 \pm 0.76)$ were ranked $4^{\text {th }}$ to $5^{\text {th }}$, respectively on the basis of farmers' perception about the impact of climate change on the crop productivity. Similar findings were presented by FAO (2009).

Table 8 unveils the farmers' perception about the coping strategies adopted by the farmers regarding climate change. It was observed that 'grow recommended varieties now than past decades' (2.58 \pm 0.72$)$, Use of more industrial pesticides now than in past decades $(2.50 \pm 0.76)$ and Practicing crop diversification (2.36 \pm 0.81$)$, Increased use of irrigation (2.19 $\pm 0.89)$ and Integrated farming system $(2.15 \pm 0.91)$ were the major coping strategies ranked $1^{\text {st }}$ to $5^{\text {th }}$, respectively. While, zero tillage $(1.66 \pm 0.87)$, Use of drought tolerant varieties $(1.61 \pm 0.43)$, Use of salinity tolerant varieties $(1.61 \pm 0.50)$, Practice mixed cropping more than past decades $(1.52 \pm 0.61)$, Cultivating short duration crops (1.36 \pm 0.68$)$ and Practicing inter cropping $(1.35 \pm 0.42)$ were ranked $6^{\text {th }}$ to $11^{\text {th }}$, respectively.

Table 7. Farmers' opinion about impact of climate change on crop productivity $(n=408)$.

Impact of climate change on crop Mean S.D. Rank productivity

Crop production in general is not

$\begin{array}{lll}2.72 & 0.62 & 1\end{array}$

enough to meet the needs of the

people

$\begin{array}{llll}\text { If our agriculture products remain } & 2.72 & 0.53 & 2\end{array}$

decreasing, we shall have to face

food shortage in the future

Increased ratio of salt in fertile land $\begin{array}{llll}2.68 & 0.58 \quad 3\end{array}$

leads to low crop production

$\begin{array}{llll}\text { The irregular seasons have badly } & 2.65 & 0.64 & 4\end{array}$

affected the crop productivity

The intensity of season has led to $\begin{array}{llll}2.56 & 0.76 \quad 5\end{array}$

decrease the nutrient of crops

Scale: $1=$ Disagree, $2=$ Neutral, $3=$ Agree

Table 8. Means, standard deviation and rank order of farmers' perception about coping strategies being adopted by the farmers regarding climate change.

\begin{tabular}{lccc}
\hline Coping strategies & Mean & S.D. & Rank \\
\hline $\begin{array}{l}\text { Grow recommended varieties now } \\
\text { than past decades }\end{array}$ & 2.58 & 0.72 & 1 \\
$\begin{array}{l}\text { Use of more industrial pesticides now } \\
\text { than in past decades }\end{array}$ & 2.50 & 0.76 & 2 \\
Practicing crop diversification & 2.36 & 0.81 & 3 \\
Increased use of irrigation & 2.19 & 0.89 & 4 \\
Integrated farming system & 2.15 & 0.91 & 5 \\
Zero tillage & 1.66 & 0.87 & 6 \\
Use of drought tolerant varieties & 1.61 & 0.43 & 7 \\
Use of salinity tolerant varieties & 1.61 & 0.50 & 8 \\
Practice mixed cropping more than & 1.52 & 0.61 & 9 \\
past decades & & & \\
Cultivating short duration crops & 1.36 & 0.68 & 10 \\
Practicing inter cropping & 1.35 & 0.42 & 11 \\
Moved to Non-farm activities & 1.35 & 0.69 & 12 \\
Soil conservations techniques & 1.32 & 0.46 & 13 \\
Agro forestry & 1.29 & 0.61 & 14 \\
Using multiple cropping pattern & 1.28 & 0.58 & 15 \\
\hline
\end{tabular}




\begin{tabular}{llll}
\hline Water conservations techniques & 1.27 & 0.49 & 16 \\
Crop insurance & 1.16 & 0.46 & 17 \\
\hline
\end{tabular}

Scale: 1 = Disagree, $2=$ Neutral, $3=$ Agree

Whereas, moved to non-farm activities $(1.35 \pm 0.42)$, soil conservations techniques $(1.32 \pm 0.46)$, agro forestry (1.29 \pm $0.61)$, using multiple cropping pattern $(1.28 \pm 0.58)$, water conservations techniques $(1.27 \pm 0.49)$ and crop insurance $(1.16 \pm 0.46)$ were ranked the lowest $12^{\text {th }}$ to $17^{\text {th }}$, respectively. Ullah (2017) and Fadina and Barjolle (2018) also recommended improved seed varieties, chemical fertilizers and pesticides to reduce the effects of climate change.

Factors affecting coping strategies regarding the impact of climate change: The impact of study variables on coping strategies about weather variation has been studied by using the logit model (Table 9). The value of log-likelihood (-2LL) is 174.26 indicates that the effect of independent variables through the purposed model is significant and hence model estimation or fit of the model has been improved. There are two further statistics required to explain the features of the model. First is Cox and Snell $\mathrm{R}^{2}$ whose value is 0.609; indicates that $61 \%$ of total variation is explained by the independent variables in the chosen model and $39 \%$ by the other variables and/or by chance. Second is Nagelkerke $\mathrm{R}^{2}$ whose value is 0.818 ; indicates that $82 \%$ of total variation is explained by the independent variables in the chosen model and $18 \%$ by the other variables and/or by chance. Both of these measures technically called pseudo $\mathrm{R}^{2}$ and its value could hardly be tested through inferential approaches of the statistics (Menard, 2000). Resultantly, it could not be considered the good measure of goodness of fit for the purposed model (Hosmer and Lemeshow, 2000).

Table 9. Binary Logistic Model.

\begin{tabular}{lrrlc}
\hline Variables & \multicolumn{1}{c}{ B } & Wald & \multicolumn{1}{c}{ Sig. } & $\operatorname{Exp(B)}$ \\
\hline Age & -0.828 & 3.197 & $0.074^{\mathrm{NS}}$ & 0.437 \\
Edu & 0.549 & 7.885 & $0.005^{* *}$ & 1.731 \\
Income & 0.575 & 4.633 & $0.031^{*}$ & 1.777 \\
Family type & 0.742 & 4.462 & $0.035^{*}$ & 2.101 \\
Experience & 1.934 & 13.907 & $0.000^{* *}$ & 6.914 \\
Size of land & 0.224 & 0.564 & $0.453^{\mathrm{NS}}$ & 1.250 \\
holding & & & & \\
Impact & -1.797 & 11.871 & $0.000^{* *}$ & 6.158 \\
Constant & -14.830 & 64.779 & $0.000^{* *}$ & 0.000 \\
\hline
\end{tabular}

Dependent variable: Adoption of coping strategies, $* *=$ significant at $<1 \%$; $=$ significant at $<5 \%$ and NS = Non-significant.

Age of selected farmers: It was found that in the study area that the increase in age contributes in decrease adoption of coping strategies to cope climate changes by the selected farmers. Odds ratio for the variable age is 0.437; explained that each one-unit increase in the age will likely to decrease 0.437 times chances for the adoption of coping strategies to cope climate changes was improved. The P-value indicates that there is non-significant relation of age with the adoption of coping strategies to cope climate changes in the study area. These results are opposite to those of Ali and Erenstein (2017) who reported that age of farmer were having positive and significant impact on the utilization of adaptive techniques.

Education of selected farmers: Increase in education significantly contributes in adoption of coping strategies to cope climate changes of selected farmers. The odds ratio for the explanatory variable education is 1.731 and it tells that if the education of farmers will be enhanced by one-unit (a year of further schooling) then there are 1.731 times chances for adopting the coping strategies towards climate change will likely to be improved. Similar results were found by Ali and Erenstein (2017) who conluded that education level of farmers have positive and significant impact on the utilization of adaptive techniques for climate changes.

Income of selected farmers: The variable income indicates the collective income of the selected farmers from all legitimate sources. The estimated coefficient of income is positive and significant. It indicates that there is a positive relation between adoption of coping strategies and the income of farmer. The odds ratio of income is 1.777 and it explained that for each unit increase of farmer's income, there will be 1.78 times more chances for adopting the coping strategies by farmer. Bryan et al. (2009) also found that the farmers' income influence on their adoption level of coping strategies against climate changes.

Agricultural experience of farmers: Agricultural experience of farmers contributes in adoption of coping strategies to cope climate changes of selected farmers. The odds ratio of variable named "experience" is 6.914 which explained that for each unit increase in the agricultural experience, there are 6.914 times chances that adoption of coping strategies towards climate changes will be improved. The positive sign shows that experienced farmers had more adoption of coping strategies to cope climate changes. Similarly, the conclusions of present research are in accordance with those of Adger $e t$ al. (2003) who found that the farmers' experience had positive relation with adoption of coping strategies related to weather variation.

Size of land holding: It is found that the size of land holding had no impact on adoption of coping strategies against climate change in the study area. The results of present study are contradictory to those of Abid et al. (2015). They found that size of land holding and adaptation to the climate change were having positive relationship.

Impact: The positive and significant coefficient of variable "impact of climate change" implies a negative relation between impact of climate change on crop productivity and adoption of coping strategies towards climate change. The value of its odds ratio is 6.158 indicates that per unit increase in the impact related to agriculture likely to enhance the adoption of coping strategies against climate change. So, it is 
clear these findings that coping strategies reduced the effects of climate changes on crops.

The binary logistic model has been also used by Abid et al. (2015) in analyzing their research data. Their findings told that the choice of farmers to adopt coping strategies towards the climate change were affected by the education level of farmers, family size, land holding, information about weather forecasts and availability of agriculture extension services.

Conclusions: It is concluded that education level of the farmers was low in the study area. It was noted that most farmers were having small land holding with self-cultivation. It was observed that long summer and short winter season and high temperature were the major perceptions concerned for the consequences of climate change in the study area. It was found that industrial smoke, excessive cutting of forest and human activities were the major causes of climate change in the study area. A vast majority of the selected farmers reported that climate change affected negatively their crop production and productivity. So, majority of the farmers were in view that their annual income is decreased due to climate change. A very small proportion of the farmers had knowledge about any agricultural institution working for climate change in the Punjab, Pakistan. It was found that 'growing recommended varieties, use of more pesticides and practicing crop diversification, increased use of irrigation and integrated farming system were the major coping strategies for controlling the effect of climate change. Bivariate analysis showed that farming experience and coping strategies is negatively associated with the impact of climate change on crop productivity.

\section{REFERENCES}

Abid, M., J. Scheffran, U.A. Schneider and M. Ashfaq. 2015. Farmers' perceptions of and adaptation strategies to climate change and their determinants: the case of Punjab province, Pakistan. Earth Syst. Dynam. 6:225-243.

Adger, W., S. Huq, K. Brown, D. Conway and M. Hulme. 2003. Adaptation to Climate Change in the Developing World. Prog. Develop. Stud. 3:179-195.

Afzal, M. and A.M. Akhtar. 2013. Factors affecting carbon sequestration in trees. J. Agric. Res. 51:61-69.

Aggarwal, P. and M.V. Sivakumar. 2011. Global climate change and food security in South Asia: An adaptation and mitigation framework. Climate Change and Food Security in South Asia, Springer; pp.253-275.

Ahmad, M., M. Iqbal and M. Khan. 2013. Climate Change, Agriculture and Food Security in Pakistan: Adaptation Options and Strategies. Pakistan Institute of Development Economics, Islamabad, Pakistan (Climate Change Brief).

Akhtar, I. 2011. An analysis of knowledge, skills and attitude of vegetable growers regarding pesticide use for sustainable environmental health in the Punjab, Pakistan. Ph.D. Thesis, Department of Agri. Ext., Univ. of Agri., Faisalabad, Pakistan.

Ali, A. and O. Erenstein. 2017. Assessing farmer use of climate change adaptation practices and impacts on food security and poverty in Pakistan. Climate Risk Manage. 16:183-194.

Anon. 2007. Climate change 2007: Impacts, adaption and vulnerability. Working group II contribution to the Intergovernmental Panel on Climate Change (IPCC) Fourth Assessment Report, Brussels.

Arshad, A.W. 2009. Adoption of weed management practices among sugarcane growers of Tehsil Samundri, District Faisalabad. M.Sc. (Hons.) Agricultural Extension Thesis, Univ. of Agri., Faisalabad, Pakistan.

Bryan, E., T.T. Deressa, G.A. Gbetibouo and C. Ringler. 2009. Adaptation to climate change in Ethiopia and South Africa: Options and constraints. Environ. Sci. Policy 12:413-426.

Challinor, A., J. Watson, D. Lobell, S. Howden, D. Smith and N. Chhetri. 2014. A meta-analysis of crop yield under climate change and adaptation. Nat. Clim. Change 4:287-291.

Church, J.A., P.U. Clark, A. Cazenave, J.M. Gregory, S. Jevrejeva, A. Levermann, M.A. Merrifield, G.A. Milne, R.S. Nerem, P.D. Nunn, A.J. Payne, W.T. Pfeffer, D. Stammer and A.S. Unnikrishnan. 2013. Sea level change. In: Climate Change 2013: The Physical Science Basis.

Daze, A. 2011. Understanding vulnerability to climate change: insights from application of CARE's climate vulnerability and capacity analysis (CVCA) methodology. In C.C.N., E.A. (Ed.), Care Poverty. pp. 124.

Edeoghon, C.O., M.T. Ajayi and T.O. Ugboya. 2008. Awareness and use of sustainable agricultural practices by arable crop farmers in Ikpoba Okha local government area of Edo State. J. Sust. Dev. Agri. Envir. 3:55-63.

Fadina, A.M.R. and D. Barjolle. 2018. Farmers' adaptation strategies to climate change and their implications in the Zou Department of South Benin. Environments 5:15; doi:10.3390/environments5010015.

FAO. 2009. Coping with a changing climate: considerations for adaptation and mitigation in agriculture. Sales and Marketing Group - Communication Division Food and Agriculture Organization of the United Nations Viale delle Terme di Caracalla - 00153 Rome, Italy.

Farooq, A.B. and A.H. Khan. 2004. Climate change perspective in Pakistan. Proceedings Capacity Building APN Workshop on Global Change Research, Islamabad, Pakistan; pp.39-46.

Fawole, O.P. 2006. Poultry farmers' utilization of information in Lagelu local government area, Oyo state of Nigeria. Int. J. Poult. Sci. 5:499-501. 
Field. 2014. Technical Summary. In: Climate Change 2014: Impacts, Adaptation, and Vulnerability. Part A: Global and Sectoral Aspects. Contribution of Working Group II to the Fifth Assessment Report of the Intergovernmental Panel on Climate Change [Field, C.B., V.R. Barros, D.J. Dokken, K.J. Mach, M.D. Mastrandrea, T.E. Bilir, M. Chatterjee, K.L. Ebi, Y.O. Estrada, R.C. Genova, B. Girma, E.S. Kissel, A.N. Levy, S. MacCracken, P.R. Mastrandrea, and L.L. White (eds.)]. Cambridge University Press, Cambridge, United Kingdom and New York, NY, USA; pp. 35-94.

Govt. of Pakistan. 2013. Framework for implementation of climate change policy (2014-2030). Climate Change Division Islamabad, Government of Pakistan.

Govt. of Pakistan. 2017. Economic Survey of Pakistan 201617. Ministry of Finance, Govt. of Pakistan, Islamabad, Pakistan.

Hartmann, D.L., A.M.G. Klein Tank, M. Rusticucci, L.V. Alexander, S. Brönnimann, Y. ChaRabi, F.J. Dentener, E.J. Dlugokencky, D.R. Easterling, A. Kaplan, B.J. Soden, P.W. Thorne, M. Wild and P.M. Zhai. 2013. Observations: Atmosphere and Surface. In: Climate Change 2013. The Physical Science Basis. Contribution of Working Group I to the Fifth Assessment Report of the Intergovernmental Panel on Climate Change. Cambridge University Press, Cambridge, United Kingdom and New York, NY, USA; pp.159-254.

Hosmer, D.W. and S. Lemeshow. 2000. Applied logistic regression. John Wiley and Sons, New York, USA.

Huertas, A. 2015. Dear Humans: Industry is Causing Global Warming, Not Your Activities. Union of Concerned Scientists, Science for a healthy planet and safer world.

Hussain, S.S. and M. Mudassar. 2007. Prospects for wheat production under changing climate in mountain areas of Pakistan - An econometric analysis. Agr. Sys. 94:494501.

Huong, N.T.L., Y.S. Bo and S. Fahad. 2017. Farmers' perception, awareness and adaptation to climate change: evidence from northwest Vietnam. International Journal of Climate Change Strategies and Management. 9: 555576; doi.org/10.1108/IJCCSM-02-2017-0032.

IPCC. 2007a. Climate Change 2007: Impacts, Adaptation and Vulnerability. Cambridge: Cambridge University press.

IPCC. 2007b. Climate Change 2007: Impacts, adaptation and vulnerability: contribution of Working Group II to the fourth assessment report of the Intergovernmental Panel on Climate, Cambridge University Press, United Kingdom.

Lewis, A. 1997. Evolution of farm management information systems. Computers Electronics Agric. 19:233-248.

Lyngdoh, E.K. and R. Baishya. 2010. People's perception on the effect of climate change- A case study from Meghalaya. Reflections of Climate Change Leaders from the Himalayas, Leadership for Environment and Development (LEAD) report, New Delhi, India.

Mahato, A. 2014. Climate change and its impact on agriculture. Int. J. Scient. Res. Publ. 4:1-6.

Mansoor, H. 2008. Family System in Pakistan. Asian Women Magazine. Available online at http://ezinearticles.com/?Family-System-inPakistan\&id $=1025541$

Mehmood, N. 2011. Implication of the adoption of water saving irrigation intervention for enhancing wheat yield at small farms of District Faisalabad. Ph.D. Thesis, Department of Agricultural Extension, Univ. of Agri., Faisalabad, Pakistan.

Menard, S. 2000. Coefficients of determination for multiple logistic regression analysis. The American Statistician 54:17-24.

Ofuoku, A.U., G.N. Emah, and B.E. Itedjere. 2008. Information utilization among rural fish farmers in Central Agricultural Zone of Delta state, Nigeria. World J. Agric. Sci. 4:558-564.

Osada, A., V. Sairapa, M. Raliong, S. Dhammanuvong and H. Chakrabandlue. 1973. Abnormal occurrence of empty grains of indica rice plants in the dry, hot season in Thailand. Proc. Crop Soc. Jpn. 42:103-109.

Oxfam International. 2009. Even the Himalayas have stopped smiling: Climate change, poverty and adaptation in Nepal. Oxfam International, Nepal.

Peng, C.Y., T.S. So, F.K. Stage and E.P. St. John. 2002. The use and interpretation of logistic regression in higher education journals 1988-1999. Educ. Res. High Educ. 43:259-293.

Porter, J.R., L. Xie, A.J. Challinor, K. Cochrane, S.M. Howden, M.M. Iqbal, D.B. Lobell, M.I. Travasso. 2014. Chapter 7: Food Security and Food Production Systems Climate Change 2014: Impacts, Adaptation and Vulnerability (Part A: Global and Sectoral Aspects. Contribution of Working Group II to the Fifth assessment Report of the Intergovernmental Panel on Climate Change). Cambridge University Press.

Smit, B. and M.W. Skinner. 2002. Adaptation options in agriculture to climate change: a typology. Mitig. Adapt. Strat. Glob. Change. 7:85-114.

Sultana, H. and N. Ali. 2006. Vulnerability of wheat production in different climatic zones of Pakistan under climate change scenarios using CSM-CERES-Wheat Model. In: Second International Young Scientists' Global Change Conference, Beijing, China; pp.7-9.

Tadesse, D. 2008. Access and utilization of agricultural information by resettler farming households: the case of Metema Woreda, North Gondar, Ethiopia. M.Sc. Thesis, Dept. of Rural Dev. and Agri. Ext., School Graduate Studies, Haramaya University.

Ullah, W. 2017. Understanding climate change vulnerability, adaptation and risk perceptions at household level in 
Khyber Pakhtunkhwa, Pakistan. Int. J. Climate Change Strat. Manage. 10:359-378; doi.org/10.1108/IJCCSM02-2017-0038

Van Aalst, M.K. 2006. The impacts of climate change on the risk of natural disasters. Disasters 30:5-18.
Watson, B. 2010. Climate change: An environmental, development and security issue. Livestock and Global Climate Change International Conference Proceedings, Tunisia; 17-20 May 2008; pp.6-7. 